\title{
РЕАЛИЗАЦИЈА НА АНАФОРСКИОТ СУБЈЕКТ ВО МАКЕДОНСКИОТ ЈАЗИК
}

\author{
Елени Бужаровска \\ Универзитет „Св. Кирил и Методиј“, Скопје \\ elenibuzarovska@t.mk \\ Лилјана Митковска \\ Универзитет ФОН, Скопје \\ liljana.mitkovska@fon.edu.mk
}

Во овој труд ги претставуваме резултатите од истражувањето на синтаксата на анафорската референција во наративниот дискурс. Главната цел на истражувањето е да ги утврди принципите што го одредуваат реализирањето на анафорските субјекти во наративните текстови на македонски јазик. Текстуалната анализа на избраните наративи опфаќа три формални категории субјекти со кои се кодираат протагонистите во наративите: „празен“ (реализиран преку личната наставка на глаголскиот предикат), заменски и именски. Добиената дистрибуција на секоја испитувана категорија се објаснува преку делувањето на когнитивниот принцип според кој изборот на формата на субјектот зависи од менталната достапност на субјектниот референт во меморијата на слушателот/читателот. Меѓутоа, овој принцип може да се наруши под влијание на други принципи кои предизвикуваат отклонувања од предвидените реализации на анафорските субјекти. Резултатите на анализата ја потврдија главната хипотеза дека формата на субјектот се одредува од заемодејството на когнитивниот принцип со семантички, синтаксички и дискурсно-прагматички принципи. Делувањето на секој од разгледуваните принципи се објаснува преку примерите од анализираните текстови.

Клучни зборови: анафора, заменки, субјект, референција, кохезија, дискурс 


\title{
THE REALIZATION OF ANAPHORIC SUBJECTS IN MACEDONIAN
}

\author{
Eleni Bužarovska \\ Ss Cyril and Methodius University, Skopje \\ elenibuzarovska@t.mk \\ Liljana Mitkovska \\ FON University \\ liljana.mitkovska@fon.edu.mk
}

This paper presents the results of the investigation into the syntax of anaphoric reference in narrative discourse. The main goal is to determine the principles that govern the realization of anaphoric subjects in Macedonian narratives. The analysis focuses on three types of subjects that code the protagonists in chosen narrative texts: implicit (signaled by verbal personal inflections), pronominal and nominal. The obtained distribution of each subject category is accounted for by positing a cognitive default principle according to which the form of the anaphor is governed by the cognitive status of its referent in listener/reader's memory. However, this cognitive principle may be superseded by the effects of other principles which cause deviations in the expected realization of anaphoric subjects. The results of the analysis confirm the main hypothesis that the choice of the subject form depends on the interplay of cognitive, semantic, syntactic and discourse-pragmatic principles. The effect of each principle is explained using the data from the analyzed narratives.

Key words: anaphora, subject, pronoun, reference, cohesion, discourse 


\section{1 Вовед}

Во овој труд се разгледува синтаксата на анафорската референција во наративниот дискурс. Наративот е текст што опишува хронолошки поврзани случки во кои учествуваат еден или повеќе учесници познати како протагонисти. Протагонистот е во центарот на настаните и во фокусот на вниманието на раскажувањето, и затоа обично е субјект во реченицата (van Hoek 1997: 114).

Со оглед на фактот дека протагонистот на настаните опишани во наративот е обично човек што е воведен на почетокот, понатаму тој е познат за читателот/слушателот и претставува реченична йема која типично се реализира во субјектна позиција. Од перспектива на информациската структура на една прототипна реченица, реченичната тема носи стара, односно пресупонирана информација додека останатиот дел од реченицата претставува нова информација, односно рема. ${ }^{1}$ Терминот реченична йема го користиме за предметот/личноста за која станува збор во реченицата (т.е. на реченично ниво $)^{2}$ и затоа треба да се разликува од терминот $\bar{\varkappa} е м а$ кој се однесува на целиот текст или дел од текстот (т.е. функционира на дискурсно ниво).

Еден текст се смета за кохерентна целина, а не за хаотичен збир реченици, ако речениците се поврзани со кохезивни средства и се обединети со иста тема (односно изразуваат информации во врска со таа тема) и така го прават текстот кохерентен. Речениците меѓусебно се поврзуваат преку различни кохезивни средства. Фокусот на ова истражување е на анафорската референција како едно од кохезивните средства меѓу речениците во еден текст, а субјектните анафори играат примарна улога за кохезијата и кохерентноста на текстот. Според Гивон (Givón 2001: 254), под терминот ‘анафора' се подразбира збир на граматички средства кои му овозможуваат на слушателот да го лоцира протагонистот за кој станува збор во претходниот текст. Во ова истражување ги разгледуваме анафорските реализации на субјектот во наративен текст во македонскиот јазик за да утврдиме од кои фактори зависи која форма ќе биде употребена.

За да ги именува и за да ги посочува протагонистите во текстот нараторот користи референциски изрази во вид на именски или во вид на заменски форми. Тоа подразбира дека функцијата на референциските изрази во текстот, пред cè, e семантичка (Runge 2006) бидејќи тие ги идентификуваат

\footnotetext{
${ }^{1}$ Според принципот на природното процесирање на информацијата (Natural Information Flow) формулиран од Комри (Comrie 1989: 127-128), говорителот вообичаено го структурира исказот почнувајќ́ од позната информација на која се надоврзува новата.

${ }^{2}$ Во современите проучувања на дискурсот објавени во научната литература на англиски јазик се употребува терминот йойик наместо иеема.
} 
посочените референти надвор од текстот и му овозможуваат на читателот или на слушателот да ја следи улогата на секој партиципант во раскажуваните настани и ситуации. Изборот на формата нареференциските изрази зависи од функцијата што ја имаат во текстот: дали го воведуваат протагонистот, дали продолжуваат да го спомнуваат, или повторно го воведуваат по одредена пауза. Зависно од формата на кохезивното средство слушателот или читателот ја активира меморијата за да го идентификува протагонистот за кој станува збор и да го следи текот на раскажувањето.

Кога субјектниот референт се воведува за првпат во дискурсот тој обично има форма на неопределена именска синтагма (ИС), а понатаму се кодира со определена ИС, лична заменка или празна позиција, односно личната глаголска форма (ЛГФ) која укажува на идентитетот на референтот. Така, во

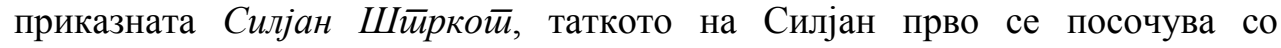
неопределената синтагма еgен човек, а потоа со лично име Божин (1). Втората реченица се поврзува со првата преку анафорската заменка $\bar{u} о j$ и се однесува на Божин. Во (2) протагонистот Силјан е веќе познат и затоа во втората реченица е реализиран со имплицитен субјект (Ø), изразен во глаголската наставка за 3 л. еднина слушаше.

(1) Во село Мало Коњари имаше еден човек1 многу чесен и кроток, на име Божин. Тој 1 имаше само еден син на име Силјан. ${ }^{3}$

... арно ама Силјан 2 беше фатил еден лош пат, тики ич $\varnothing_{2}$ не го слушаше татка си и мајка си.

Од типолошка гледна точка, во јазиците во светот се користат следните средства за кодирање на кохезивна релација (Givón 1983): нулта анафора (без никакви формални знаци за упатување), клитика/афикс, неакцентирана анафорска заменка, акцентирана независна заменка, определена ИС, неопределена ИС и модификувана ИС. ${ }^{4}$ Македонскиот јазик типолошки припаѓa во јазиците во кои личната заменка во субјектната позиција во финитни реченици може да не се реализира заради тоа што референтот на субјектот се идентификува од личните наставки на глаголскиот предикат. Нереализираните субјекти во таквите јазици се кореферентни со претходно спомнат референт (антецедент) преку егзофорична или ендофорична референција. Со истите кохезивни средства располага македонскиот јазик. Така 'нулта' анафора ја сметаме како имплицитен субјект (Ø) со нефинитни

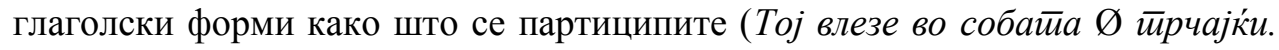

\footnotetext{
${ }^{3}$ Со индекс (подзнак) ги бележиме кореферентните конституенти на реченицата.

${ }^{4}$ Гивон (Givón 1983) овие кохезивни средства ги нарекува анафорска референција. Треба да се истакне дека под терминот 'анафора' традиционално се подразбира главно употреба на заменките. Како што забележуваат Браун и Јул (Brown and Yule 1983: 215): "For obscure historical reasons, the term anaphora, as it is generally used, is restricted almost exclusively to pronominal referring expressions."
} 


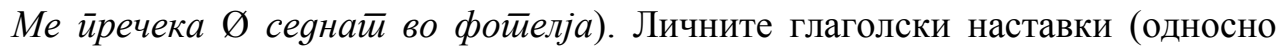
'афикси') и клитиките, кои се обележани по категориите лице, број и род, помагаат во идентификување на референтот: флексиите посочуваат на имплицираниот субјект (Ø), а клитиките се кореферентни со определениот, често испуштен објект (Ø субј Го вияов $\left.\varnothing_{\text {обј }}\right)$. Неакцентираните анафорски заменки се однесуваат на 3 лице претходно спомнато во текстот ( $\bar{u} о j, \bar{u} a a$,

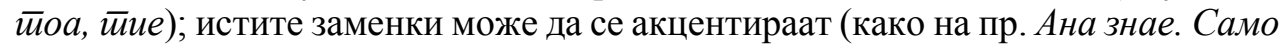
ТАА може ga $\bar{u} и$ каже). Определените ИС посочуваат на познат референт на соговорникот па затоа може да имаат и анафорска функција, за разлика од неопределените ИС кои воведуваат нов непознат референт во дискурсот. Модификуваната ИС содржи атрибутивна определба, на пр. йалаво geӣe, gлабока река и сл.

Сметаме дека личната глаголска форма, како најмалку маркирано кохезивно средство, се одликува со висока способност за анафорска поврзаност бидејќк упатува на близина со кореферентниот израз. Таа не го прекинува текот на темпорално наредени настани, не го попречува протокот на информации во умот: присутноста на референтот во меморијата го прави лесно достапен за когнитивно процесирање. Од друга страна, заменката, а посебно ИС се помаркирани кохезивни средства кои се употребуваат при одредени услови кои треба да ги утврдиме. За таа цел спроведовме истражување за реализација на субјектната анафора во следните македонски

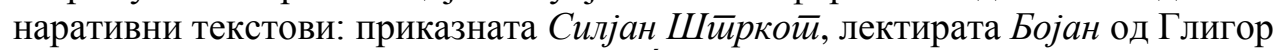
Поповски, дел од романот Пусйина од Ѓорѓи Абаџиев, дел од расказот Болеро од Румена Бужаровска.

Во нашето истражување поаѓаме од хипотезата на Гивон (Givón 1983) за т. н. референциски или тематски континуитет : изборот на лексичката форма со која се реализира субјектот зависи од неговото растојание од антецедентот. Тоа подразбира дека постои корелација меѓу анафорското растојание и формата на субјектот. Таа корелација е градена според принципот на иконичност: колку е подалеку претходната референција на субјектот толку повеќе треба јазичен материјал за да се кодира бидејќ така полесно слушателот или читателот ќ се сети на референтот на кого се однесува. Таквата зависност може графички да се претстави како импликативна скала или континуум, на која се „наредени“ потенцијалните реализации на субјектот во определен импликативен ${ }^{6}$ редослед. Скалата покажува дека субјектна именска синтагма (ИС) се користи кога претходно спомнатиот субјектен референт е најоддалечен, додека ЛГФ (испуштен

\footnotetext{
5 Англ.: topic continuity.

${ }^{6}$ Импликативна скала подразбира дека самиот редослед на вредностите што претходат на дадената вредност на скалата импликува дека тие вредности треба претходно да се реализираат за да се реализира следната вредност. На пр. на скалата со вредности $a, \sigma, 6, \bar{z}, g$... постоењето на вредноста $\overline{2}$ подразбира постоење на вредноста $в$.
} 
субјект) сигнализира дека референтот е актуелен во тековниот дискурс и е спомнат во претходната реченица.

Низок

Референциски континуитет (РК)

неопред. > опред. > акц. > неакц. > клит./афикс > анаф. ИС ИС заменка заменка нула

Слика 1. Хиерархија на употреба на кохезивните средства (Givón 1983)

РК го одразува когнитивниот принцип на ментална достапност на субјектниот референт во нашата меморија. Теоријата за ментална достапност (Accessibility Theory) предложена од Ариел (Ariel 1988) се надоврзува на Гивоновата хипотеза за принципот на иконичност. Основното становиште на оваа теорија е дека формата на референцискиот израз зависи од менталната достапност на референтот „складирана“ во меморијата на слушателот/читателот. Референциските изрази се разликуваат по степенот на активирање на референтот во меморијата на слушателот/читателот. Употребата на анафорска ИС означува низок степен на ментална достапност на референтот за разлика од ЛГФ, која сигнализира дека референтот е постојано присутен во меморијата на слушателот, односно читателот. Затоа, референтот кодиран со ЛГФ се одликува со висок степен на референциски континуитет (РК) во текстот.

Главната хипотеза на ова истражување е дека изборот на референциските изрази за субјектната анафора се определува од когнитивниот принцип на ментална достапност (мерливо преку РК), кој делува во спрега со повеќе универзални принципи. Заемодејството на тие принципи предизвикува варијабилност во изборот на анафорските референциски изрази. Треба да се истакне дека и самиот контекст придонесува за правилното поставување на кореферентната врска меѓу формата на субјектот и нејзиниот антецендент во текстот (Brown and Yule 1983: 49).

\section{2 Теориска рамка}

Во претходната дискусија ја изложивме тезата за врската меѓу менталната достапност на субјектниот референт и улогата на тој референт во дискурсот. Менталната репрезентација за референтот во нашата меморија се менува во текот на слушањето или читањето на наративот зависно од неговата присутност во опишаните настани. Во предметната литература прифатено е 
дека референтот може да има активен, полуактивен и неактивен когнитивен статус (Givón 1983: 17-18; Chafe 1987: 22) и дека постои корелација помеѓу статусот на референтот во дискурсот и формата на референцискиот израз со кој тој се кодира.

Активните партиципанти му се познати на слушателот/читателот и се во центарот на вниманието на нараторот. Обично тие се кодираат со минимални морфолошки форми (Gundel et al. 1993: 278; Lambrecht 1994: 96), ${ }^{7}$ како што се ЛГФ во јазиците со сочувани глаголски флексии за лице (македонскиот, шпанскиот, италијанскиот и др.), наспроти личните заменки во јазиците каде што глаголите ги изгубиле личните наставки (англискиот, германскиот, францускиот и др.), а тоа се компензирало со задолжително присуство на субјектната заменка. За разлика од нив, полуактивен статус имаат референти воведени во дискурсот но кои се спомнуваат по одредени паузи, и затоа се реактивираат во форма на заменка. Неактивните референти се потешко достапни во меморијата бидејќи се повремено присутни во дискурсот затоа што се повторно употребени по релативно големи паузи. Следствено, тие се кодираат со повеќе јазичен материјал, а тоа се определените ИС или личните имиња.

Според Гивон (1983), дистрибуцијата на референциските форми во еден текст се одредува од анафорското растојание (АР). Но, во практиката оваа претпоставка не се потврдила целосно. Имено, текстуалните анализи (на пр. Fox 1987, Clerk 2000, Runge 2006) покажуваат дека ИС се употребува наспроти очекуваната заменка, или пак заменката се појавува наместо личната глаголска наставка.

Од тие причини, методата на квантификација на АР наиде на критика од неколку автори (на пр. Tomlin 1987; Fox 1987), кои сметаат дека линеарното броење на речениците меѓу субјектот и неговото претходно спомнување (односно АР), не ги објаснува отклонувањата во предвидените реализации на субјектот согласно референциската скала на Гивон. Според нив, формата на референцијата зависи од структурата на текстот, која е хиерархиска, а не линеарна. Секој наративен текст се состои од помали кохерентни единици обединети со иста тема: поголеми тематски целини се составени од помали целини или епизоди, кои од своја страна се сочинети од параграфи, односно секвенци. Промените во реализација на субјектот предвидена според РК се случуваат на границите на епизодите: почетоците на нови наративни целини бараат маркирано кодирање на субјектот кој понатаму се кодира со минимален јазичен материјал сѐ до воведување на нов учесник во дискурсот. Тоа значи дека именските синтагми се употребуваат на почетокот на текстуални целини бидејќ служат како сигнали за демаркација на тие

\footnotetext{
${ }^{7}$ Гундел со коавторите (Gundel, Hedberg, Zacharski 1983: 275) прават подетална класификација разликувајќ шест когнитивни статуси на референтите во дискурсот. На нивната хиерархија се наредени следните статуси: фокусирани > активирани > познати $>$ единечни (лични имиња) > идентификувани > генерички.
} 
целини, додека другите субјектни позиции се реализираат со заменки и ЛГФ. Фокс (Fox 1987) смета дека и промените поврзани со главната раскажувачка линија, исто така, предизвикуваат отстапувања од горната референциска скала.

Употреба на ИС наместо заменка (или некоја друга форма подолу на референциската скала) се случува не само при промена на една тематска целина во друга туку и при промена на концептуален домен (van Hoek 1997). Еден текст е кохерентен ако постојат не само кохезивни туку и концептуални врски меѓу кореферентните елементи. Преку тие врски се обединуваат т.н. референциски домени, односно менталните простори на наративот (Fauconnier 1994) во кои владее единство на простор, време и учесници. Во секој домен протагонистот е најважен учесник бидејќи служи како референтна точка во раскажувањето и затоа обично е субјект во реченицата. При промена на референцискиот домен се прекинува концептуалното единство на текстот, што се сигнализира со употреба на ИС.

Покрај дискурсната организација на текстот во изборот на кохезивните средства делува и прагматичкиот принцип на истакнатост на протагонистот во наративот (Levinsohn 1999; Nichols 1985). Тој партиципант се одликува со важен статус во настаните опишани во дадената наративна целина или текст, па затоа предизвикува отклонувања во предвидените реализации според скалата на РК.

Од понудениот преглед на различните ставови за принципите што делуваат врз реализацијатана кохезивниот израз станува јасно дека отклонувањата во предвидените субјектни реализации, согласно когнитивниот принцип на ментална достапност на референтот, не можат целосно да се објаснат со методата на линеарната квантификација на РК преку анафорско растојание. Затоа во овој труд се застапуваме за повеќестран пристап и сметаме дека во дистрибуцијата на анафорските форми во наративот делуваат и други принципи: семантички, синтаксички, дискурсноконцептуални и прагматички.

\section{Семанйички йринций}

Овој принцип делува при двосмислена кореферентна врска на субјектот со неговиот антецедент (Runge 2006; van Vliet 2009). Изборот на формата според горната импликативна скала може да се наруши ако постои двосмисленост за идентитетот на референтот на кој се однесува субјектот. Заменката може да се употреби наместо ЛГФ, или ИС наместо заменка кога во текстот има двајца партиципанти од ист род и број па не е јасно на кого посочува анафората. На пример, во реченицата Јован г̄о вияе Марко ког̄а йој ја йоминуваше улищайа, антецедентот на заменката $\bar{u} о j$ во зависната реченица може да биде и 
субјектот Јован и објектот Марко во главната реченица, иако заменката најчесто се толкува ${ }^{8}$ како анафора на објектот.

\section{Синйаксички ӣринциийи}

Сложената синтакса на реченицата влијае врз реализацијата на субјектот. Претпоставуваме дека во зависните реченици повеќе субјекти се реализираат како ЛГФ отколку како заменки или како ИС. Во координативните реченици, исто така, очекуваме слична дистрибуција, како што се покажало во истражувањето на Николс (Nichols 1985: 173) за рускиот јазик.

\section{Дискурсно-концеййуални йринцийи}

Хиерархиската структура на наративот влијае врз изборот на формата на субјектот. Очекуваме дека маркираните форми како што се ИС се појавуваат на границите на епизоди и секвенци. Нивната употреба може да биде предизвикана и од промена на концептуалниот домен, дигресија од главната раскажувачка линија или поради кршење на единството на околностите во опишаните настани.

\section{Праг̄майички йринцийи}

Реализацијата на субјектот може да зависи од ставот на нараторот спрема протагонистот. Се смета дека заменките во англискиот јазик се поврзани со субјективно претставување на референтот (van Hoek 1997; van Vliet 2009: 458). Личните заменки придонесуваат за акцентирање на протагонистот и предизвикуваат емпатија, а ИС наместо заменка може да се употреби ако раскажувачот сака да го „објективизира“ референтот. Претпоставуваме дека и во македонскиот текст ќе се појавуваат слични отстапувања па истражувањето има за цел да ги утврди формите што се јавуваат во такви ситуации.

Класификацијата на гореизложените принципи кои делуваат врз реализацијата на субјектната анафора помага да се согледаат универзалните законитости што владеат во дискурсот. ${ }^{9}$

\footnotetext{
8 ЛГФ во зависната реченица најчесто се толкува како кореферентна со субјектот на главната

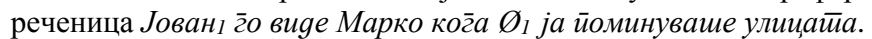

${ }^{9}$ На пр. Травис и Калкулос (Travis and Calcoullos 2012: 148) ги набројуваат контекстите во кои се реализира субјектната заменка во шпанскиот јазик: кога се разјаснува родот на 3 л., кога се истакнува или повторно се воведува референтот, кога се менува просторот и времето, кога се изразува контраст или реченична рема.
} 


\section{3 Методологија на истражувањето}

Основната цел на ова истражување е да ги откриеме законитостите во реализацијата на субјектот преку утврдување на дистрибуцијата на реализираните субјекти на текстуално ниво. За да ја докажеме главната хипотезата дека изборот на референциските изрази за субјектот се определува со заемодејството на когнитивниот принцип со другите принципи изложени погоре ги испитуваме следните три категории на реализација на субјект:

а. средства со висок референциски континуитет: лична глаголски форми (ЛГФ) $(\varnothing)^{10}$;

б. средства со среден референциски континуитет: лични заменки (ЛЗ); и

в. средства со низок референциски континуитет: именска синтагма

(ИС)/лично име.

Во анализата ја применивме следната истражувачка постапка: прво ги издвоивме главните учесници во извадокот од наративот и го поделивме текстот на јадрени реченици. Вкупно беа анализирани субјектите на 358 јадрени реченици: 158 во Силјан Шӣркой, 90 во Бојан, 61 во Пустиина и 49 во Болеро. Потем ги обележавме и ги избројавме само субјектните позиции на главните протагонисти во матричните и во зависните реченици. Секоја субјектна реализација беше обележана со број што го означува анафорското растојание: со 1 ако референтот е субјект во претходната реченица, со 2 ако е пред две реченици, со 3 - пред три реченици и т. н. Најголемото растојание (20 јадрени реченици) има неопределена ИС чиј референт за прв пат се воведува во дискурсот. Во следната фаза ги собравме сите вредности на секоја од трите формални категории и ја утврдивме средната вредност на секоја категорија. Средната вредност ја покажува честотата на спомнувањето на субјектниот референт во обработените наративни текстови. На крај, врз база на квантитативните податоци ги објаснуваме причините за отклонувањата во изборот на субјектните форми според референциската скала на Гивон (Givón 1983).

\section{4 Анализа}

Прво ги претставуваме резултатите од пресметувањето на анафорското растојание (АР) во Табела 1, по што следи анализа на секоја испитувана

\footnotetext{
${ }^{10}$ Во ова истражување не се разгледува субјектната нулта анафора бидејќи таа секогаш е задолжителна. Се јавува само со нефинитни форми во граматички условени структури, во кои нереализираниот субјект е кореферентен со субјектот од матичната реченица. Таа може да дојде пред или по нефинитната реченица, што предизвикува разлика во АР.
} 
категорија: ЛГФ, ЛЗ, лично име и определена ИС. Последните две категории се разгледуваат понатаму заедно како една категорија ИС.

Табела 1. Средна вредност на анафорското растојание за одделните референциски средства

\begin{tabular}{|c|c|c|c|c|}
\hline $\begin{array}{l}\text { Протагонист } \\
\text { Субјект }\end{array}$ & $\begin{array}{c}\text { Лична } \\
\text { глаголска } \\
\text { форма (ЛГФ) }\end{array}$ & $\begin{array}{c}\text { Лична } \\
\text { заменка } \\
\text { (Л3) } \\
\end{array}$ & Име & $\begin{array}{c}\text { Определена } \\
\text { ИС }\end{array}$ \\
\hline $\begin{array}{l}\text { Болеро } \\
\text { Ѓорѓија }\end{array}$ & 1,25 & 3,67 & 7,50 & \\
\hline $\begin{array}{l}\text { Болеро } \\
\text { бабата }\end{array}$ & 1,05 & 1,80 & & 10,00 \\
\hline $\begin{array}{l}\text { Бојан } \\
\text { Бојан }\end{array}$ & 1,19 & 1,60 & 1,70 & \\
\hline $\begin{array}{l}\text { Бојан } \\
\text { Денко и Елена }\end{array}$ & 1,00 & 3,00 & 7,00 & \\
\hline $\begin{array}{l}\text { Пусийина } \\
\text { Арсо и Глигор }\end{array}$ & 1,07 & 2,00 & 11,51 & \\
\hline $\begin{array}{l}\text { Силјан Шйркой } \\
\text { Силјан }\end{array}$ & 1,12 & 2,50 & 2,32 & \\
\hline $\begin{array}{l}\text { Силјан Шйркой } \\
\text { Дуовникот }\end{array}$ & 1,125 & & & 5,6 \\
\hline 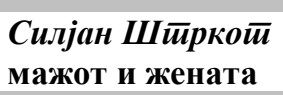 & 1,00 & 1,5 & & 2,00 \\
\hline $\begin{array}{l}\text { Вкупна средна } \\
\text { вредност: }\end{array}$ & 1,10 & 2,30 & 6,00 & 5,86 \\
\hline
\end{tabular}

Резултатите од анализата на горепосочените текстови покажуваат дека има разлика во референцискиот континуитет што се врши преку личната глаголска форма, заменката и ИС/лично име. Вкупните средни вредности се во согласност со хиерархијата на Гивон за референциските средства претставена погоре (Слика 1). Исто така и вредностите за АР на структурите кај секој одделен субјектен референт во голема мера ја следат оваа хиерархија, иако разликите не се секаде подеднакви. Тоа зависи од повеќе фактори кои се разгледуваат во анализата на одделните референциски средства во следните потпоглавја. 


\section{1 Средства со низок референциски континуитет - ЛГФ (Ø)}

ЛГФ (Ø), како најмалку маркирано кохезивно средство, се одликува со висока способност за анафорско поврзување. Таа не го прекинува текот на темпорално наредени настани, асоцира континуитет на време, простор и учесници. На Табела 2 е прикажана дистрибуцијата на овие структури според типот на реченицата.

Табела 2. Дистрибуција на ЛГФ во анализираните текстови

\begin{tabular}{ccccc}
\hline $\begin{array}{c}\text { АР }- \text { бр. на } \\
\text { реченици }\end{array}$ & $\begin{array}{c}\text { Зависна } \\
\text { реченица }\end{array}$ & $\begin{array}{c}\text { Координативна } \\
\text { реченица }\end{array}$ & $\begin{array}{c}\text { Главна } \\
\text { реченица }\end{array}$ & Вкупно \\
\hline $\mathbf{1}$ & 96 & 64 & 55 & 215 \\
\hline $\mathbf{2}$ & 5 & 10 & 2 & 17 \\
\hline $\mathbf{3}$ & 2 & 2 & 1 & 4 \\
\hline $\mathbf{4}$ & & & 58 & 1 \\
\hline Вкупно: & 103 & 76 & & 237 \\
\hline
\end{tabular}

Кај ЛГФ анафорското растојание е приближно исто за сите референти (главни и споредни) во сите извадоци и се движи од 1 до 1,25. Најголем број на ЛГФ со најмало АР (референтот е спомнат во претходната реченица) е присутен во 215 реченици, додека бројот на речениците со поголемо АР е драстично помал: преку две реченици има 17 употреби, а преку три или четири реченици се само 5 употреби.

Во долните примери, протагонистите, Силјан (3) и бабата (4) во сите понатамошни реченици се реализирани со ЛГФ заради краткото АР и единство на темата одразено во низа последователни случки опишани во епизодата.

(3) Секое одење на пазар, Силјан 1 , уште не слезен од коњ, право $\emptyset_{1}$ ќе појдеше кај лебарниците и $\emptyset_{1}$ ќе земеше еден топол сомун ас-екмек и Ø ќе си купеше тан-алва, Ø 1 та ќе јадеше.

(4) Кога $\varnothing_{2}$ ќе станеше да појадува, ${ }^{11}$ бабата 1 стоеше на прозорецот од кујната и $\varnothing_{1}$ ги гледаше минувачите како одат на работа или $\emptyset_{1}$ безобразно звереше во прозорецот на соседите отспротива. (Болеро)

${ }^{11} \varnothing_{2}$ се однесува на синот. 
Табелата 2 покажува дека употребата на кореферентни ЛГФ субјекти зависи од синтаксичката комплексност на реченицата. Тие се јавуваат најчесто во зависни реченици (103 по број), па во координативни (76) и најмалку во главни (58). Очигледно е дека постои тенденција зависниот субјект да се реализира со ЛГФ, како што е илустрирано во (5), иако во (6) и (7) не е така, тој е реализиран со лично име во (6) и со заменка во (7):

Откога Ø $\varnothing_{1}$ го докажа сето сторение негово, Силјан им се молил за и тие да му кажат од кај го познаваат и од кај го виделе. (Силјан Штркот)

(6) Иако Денко 1 е градско дете, $\varnothing_{1}$ веднаш го прифаќа Бојан, а со мали потешкотии и начинот на живот во планината. (Бојан)

На четириесет и три години живееше со ужасно параноична и љубопитна жена. Бидејќи таа 1 беше во години, наутро $\varnothing_{1}$ се будеше во пет часот и претерано гласно $\varnothing_{1}$ слушаше временска прогноза. (Болеро)

Разликите во формата на анафората во (6) и (7) може да се должат на различната позиција на зависната реченица. Зависно од тоа дали таa се наоѓa пред или по главната реченица, истата сложена реченица добива различна информациска структура. ${ }^{12}$

Поширокиот контекст може да помогне да се идентификува протагонистот и покрај големото АР. Така, во пример (8) ИС својайа луйина недвосмислено укажува на Бојан и покрај големото АР од три јадрени реченици меѓу антецендентот Бојан и неговата ЛГФ анафора во зависната комплементарна

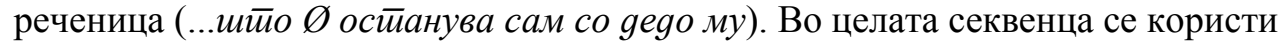
ЛГФ за серија последователни настани во кои учествува само протагонистот. Почетокот на нова тематска целина е сигнализирана со употреба на субјектна ИС (иумаро $\bar{u})$.

Бојан 1 се бори сам со себе, му фали Елена, тешко му е што не се поздравил со неа, $\varnothing_{1}$ постојано од лутина фрла камења, а капак на сѐ,

12 Според Даунинг и Лок (Downing and Locke 2006: 225), реченичниот конституент на почетокот на реченицата (прилошки израз или зависна реченица) ја поставува рамката на околностите во кои се одвива дејството на реченицата. Во склоп на оваа рамка се активира и протагонистот за кого се соопштува нешто ново во главната реченица. Така во (a) се комуницира причината за раното будење на протагонистот и субјектната заменка е акцентирана. Кога зависната реченица е во постпозиција, како во (б), таа е дел од ремата и субјектната заменка добива реченичен акцент со што се менува комуникативната цел на реченицата: во фокусот е возраста на бабата, а не нејзиното рано станување.

(a) Бидејќи таа 1 беше во години, наутро $\emptyset_{1}$ се будеше во пет часот...

(б) Наутро $\varnothing_{1}$ се будеше во пет часот, бидејќи таа 1 беше во години... 
доаѓа време и Денко и доктор Коста да си заминат. И повторно

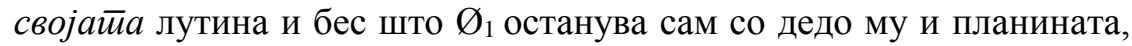
$\varnothing_{1}$ ги истура на необичен само нему својствен начин. $\varnothing_{1}$ Се качува повторно на Орелска чука, сам, непретпазливо, $\varnothing_{1}$ брзо се искачува на врвот. Таму $\varnothing_{1}$ решава да преспие. Едно претпладне, во зората на есента, шумарой носи вести во колибата. (Бојан)

\section{2 Средства со среден референциски континуитет (ЛЗ)}

Заменката како субјект се појавува при поголемо АР и како резултат на делувањето на други принципи. Дистрибуцијата на личните заменки според типот на речениците во кои се јавува и бројот на јадрени реченици меѓу заменката и антецедентот е прикажана на Табела 3. Резултатите покажуваат дека тие се јавуваат поретко во анализираните текстови: присутни се во десет зависни реченици (најголемо АР е 5), во пет координативни (најголемо АР е 4) и во седум главни реченици (најголемо АР е 4).

Табела 3. Дистрибуција на ЛЗ во анализираните текстови

\begin{tabular}{lcccc}
\hline $\begin{array}{l}\text { АР - бр. на } \\
\text { реченици }\end{array}$ & $\begin{array}{c}\text { Зависна } \\
\text { реченица }\end{array}$ & $\begin{array}{c}\text { Координативна } \\
\text { реченица }\end{array}$ & $\begin{array}{c}\text { Главна } \\
\text { реченица }\end{array}$ & Вкупно \\
\hline $\mathbf{1}$ & 4 & 2 & 3 & 9 \\
$\mathbf{2}$ & 3 & 1 & 2 & 6 \\
$\mathbf{3}$ & 1 & 1 & 1 & 3 \\
$\mathbf{4}$ & 1 & 1 & 1 & 3 \\
$\mathbf{5}$ & 1 & & & 1 \\
Вкупно: & 10 & 5 & 7 & 22 \\
\hline
\end{tabular}

Забележавме дека заменката најмалку е употребена во приказната Силјан Шйркой, само во 4 реченици, наспроти 46 со лично име/ИС и 130 со ЛГФ за анализираните протагонисти. Претпоставуваме дека тоа се должи на стилските особености на приказните кои се организирани околу главниот протагонист. Бидејќи нараторот сака да го истакне протагонистот, тој почесто употребува лично име или ИС наместо заменка кога се навраќа на референтот по одреден период. Слична редундантна лексикализација на главните протагонисти е забележана во библиските текстови (Runge 2006).

Употребата на ЛЗ може да биде поттикната од семантички, дискурсни или прагматички причини. Ќе ги разгледаме посебно овие функции на ЛЗ. 


\subsection{1 Семантичка функција (идентификација на референтите)}

Влиет (Vliet 2009: 39) ја објаснува семантичката функција на заменките како стратегија со која се следат улогите на протагонистите во дискурсот. Личните заменки може да се употребуваат под влијание на други принципи покрај когнитивниот. Така, кога има потреба за разликување на протагонистите, посебно ако не се од ист број и род, се јавува лична заменка и покрај краткото AP. Во примерот (9) употребата на заменката $\bar{u} о j$ е семантички мотивирана бидејќи без заменката (и без поширок контекст) нема да биде јасно кој стигнал до комфорот.

...како таа 2 го израснала, $\varnothing_{2}$ пелените му ги перела, $\varnothing_{2}$ млеко му греела во ниедно време, $\varnothing_{2}$ работела дење и ноќе само тој 1 да стигне до комфорот во кој $\varnothing_{1}$ е сега. (Болеро)

Заменките може да се употребат и кога постои опасност од двосмисленост, иако и контекстот помага да се разјасни за кој референт станува збор. Во (10) глаголот йочнуваше не го прецизира родот, па без заменката би можел да се сфати како кореферентен со другиот протагонист ако не се обрне поголемо внимание на поврзаноста на глаголите со целокупната ситуација.

(10) Излишно беше $\varnothing_{1}$ да стане и $\varnothing_{1}$ да ја кара глувата баба, затоа што $\mathrm{Taа}_{2}$ почнуваше да плаче и $\varnothing_{2}$ да се жали ... (Болеро)

\subsection{2 Дискурсна функција}

Л3 играат важна улога во сигнализирање на наративната структура. Личната заменка може да се појави на границата на помала секвенца во која се опишува активност или ситуација различна од претходната секвенца (11). Заменката може да означува промена на ситуацијата, како на пример серија други настани (12) или да означи контрастирање со претходната ситуација, сигнализирани преку адверсативна реченица (13) или некој прилог, како на пример сейак во (14).

(11) Една вечер, Бојан 1 забележува чад и оган на Гола Глава и низ главата му се редат мисли за тоа ... (следат уште 2 кратки реченици). Но тој 1 продолжува да вежба со пушката... (Бојан)

(12) $\quad$ Арсо 1 се мачеше да заспие... (следат16 јадрени реченици) Ноќта му се стори долга, неподнослива. Најпосле умората надвладеа и тој 1 заспа. (Пустина) 
(13) Првата вечер кога $\varnothing_{1}$ го слушна нивното завивање, стравот му се всадува. Но тој 1 е одлучен $\emptyset_{1}$ да истрае и $\emptyset_{1}$ да се фати во борба со тие крвници. (Бојан)

(14) Бојан и дедо Димо иако со тешко срце, решаваат да ја пуштат Кротка 1 , затоа што таа 1 сепак ѝ припаѓa на шумата. (Бојан)

Во следниот пример употребена е заменката $\bar{u} a a$ наместо ЛГФ, иако протагонистот се спомнува во ИС во претходната реченица, бидејќи почнува нова тематска целина во која се опишува дневната рутина на мајката. Понатаму, консекутивното спомнување на истиот референт во секоја реченица се реализира со ЛГФ заради малото АР и ситуацискиот континуитет.

(15) На четириесет и три години, ерген, живееше со ужасно параноична и љубопитна жена ${ }_{1}$. Бидејќи таа 1 си беше во години, наутро $\varnothing_{1}$ се будеше во пет часот и $\varnothing_{1}$ претерано гласно слушаше временска прогноза. Полуглува и суетна, $\varnothing_{1}$ не сакаше да си стави апаратче за уши, велејќи дека сите си вообразуваат дека $\varnothing_{1}$ е глува поради тоа што $\varnothing_{1}$ е стара. Следствено, во најраните мугри $\varnothing_{1}$ стануваше и со себе $\emptyset_{1}$ ги расонуваше сите соседи. (Болеро)

\subsection{3 Прагматичка функција}

Погоре, во поглавје 2 (г), беше објаснето дека ЛЗ и ИС имаат прагматичка функција во дискурсот што го рефлектира ставот на нараторот. Во следниот пример (16) втората употреба на $\bar{u} а a$ внесува субјективно истакнување, кое го суспендира принципот на иконичност одразен во АР. Така $\bar{u} a a$ ја потенцира улогата на бабата во настанот по кој следат тематски поврзани настани. Слична функција има и втората употреба на заменката $\bar{u} о j(\bar{u} о j ~ e$ неблаг̄ogapeн): каде што нема потенцијална двосмисленост за идентитетот на протагонистот затоа што родот е маркиран во предикатот. Тука заменката внесува динамичност и креира еден раскажувачки ритам.

(16) Излишно беше $\varnothing_{1}$ да стане и $\varnothing_{1}$ да ја кара глувата баба, затоа што таа $_{2}$ почнуваше да плаче и $\emptyset_{2}$ да се жали како тој ${ }_{1}$ е неблагодарен, како таа 2 го израснала, $\varnothing_{2}$ пелените му ги перела, $\varnothing_{2}$ млеко му греела во ниедно време ... (Болеро)

И во следните примери личната заменка $\overline{\bar{o}}$ има кратко АР, што значи дека тука е нарушен принципот на немаркирано бележење на анафори чии референти имаат висока ментална достапност. Затоа сметаме дека употребата 
на заменката $\bar{u} о j$ е прагматички мотивирана: и во двата примера протагонистот страда во немили настани и ја добива емпатијата на нараторот.

(17) Но по невремето, шумарот пристигнува со лоши вести, дека гром ги убил двете овчарчиња. Тие се училишни другари на Бојан, па оваа вест Бојан 1 тешко ќе ја прими. Неколку дена тој 1 тагува сам. (Бојан)

(18) И дедо Иван страшно се разболува, па двајцата инженери, со носилка едвај го спуштаат од Гола Глава до Гогов Валог, за потоа шумарот со џипот да го однесе на лекување. Но дедо Иван 1 не издржува и тој 1 умира. (Бојан)

Акцентирана лична заменка се употребува по сврзникот $u$, кој бара експлицитно да се именува веќе познат, пресупониран референт, па, следствено, лесно достапен за идентификување. Но употребата на заменката во (19) се должи на информациската структура на реченицата: информацискиот фокус на пропозицијата е на протагонистот кој учествува во неочекувано дејство. Да беше делувањето на протагонистот очекувано, субјектната анафора ќе се реализираше со ЛГФ.

Арно ама Силјан, парите не му ги земал, чунким $\emptyset_{1}$ сакал и тој 1 да оди на Божји гроб. (Силјан Штркот)

Употребата на ЛЗ може да биде мотивирана и од синтаксички причини, односно пред копулата сум, особено кога именскиот предикат не е поексплицитен.

(20) Кога Бојан, дознава дека Елена си заминала за Скопје, тој 1 е лут. (Бојан)

\section{3 Средства со низок референциски континуитет: ИС и лично име}

Неопределената ИС служи за воведување на протагонистот во дискурсот, како што е прикажано во (21). Протагонистот мајкайа е воведена со именката жена во рематска позиција, која е кореферентна со субјектната заменка $\bar{u} а a$ во следната реченица. ИС или име се користи и за повторно експлицитно внесување во текстот на партиципант кој е присутени на него се упатува со најмалку маркирана форма. Ако има ситуациски континуитет тоа растојание може да биде поголемо или помало, во зависност од проценката на авторот на текстот. Во (22) личното име повторно го внесува во текстот веќе познатиот партиципант идентификуван со ЛГФ во претходните четири реченици. 
(21) На четириесет и три години, ерген, живееше со ужасно параноична и љубопитна жена 1 . Бидејќи таа 1 си беше во години, наутро $\varnothing_{1}$ се будеше во пет часот и $\varnothing_{1}$ претерано гласно слушаше временска прогноза. (Болеро)

(22) Глигор 1 го здипли челото. Зошто Ø 1 го одби неговиот предлог? $\emptyset_{1}$ Ќе има сигурно расправија со него. И Ø $\varnothing_{1}$ сретнувал и во другите затвори. И секогаш тие се едни и исти: одмаздољубиви. Глигор 1 не ги поднесуваше. (Пустина)

Изборот на лично име/ИС наместо ЛГФ во македонскиот јазик генерално го следи когнитивниот принцип на менталната достапност на референтот во меморијата на слушателот или читателот. Лангакер (Langacker 2001: 154) го нарекува тоа „посочување/врамување на вниманието“ (attentional framing), кое има за цел да помогне во менталната реактивација на протагонистот и негова полесна идентификација. Тоа најчесто се случува кога постои поголемо анафорско растојание од претходното спомнување со име или ИС, што бара употреба на ИС.

Во анализираните текстови забележавме дека овој принцип се нарушува под влијание на горенаведените четири принципи, кои не делуваат подеднакво во сите текстови. Изборот на ИС/лично име наспроти заменка и

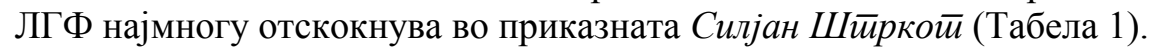

Тенденцијата за употреба на лично име наместо заменка во приказните може да се објасни со влијанието на прагматиката. Статусот на главниот лик во нарацијата се потенцира со употреба на име/ИС. Во Силјан Шйркой, на пример, за реактивација на главниот протагонист, Силјан, многу почесто се користи личното име отколку личната заменка. Во (23) би можело да се употреби заменка, но се чини дека повторувањето на името ја потенцира важноста, односно високиот дискурсен статус на ликот во приказната, со што се најавува драмски ефект во понатамошниот тек на приказната.

Силјан беше многу гален и од татка и од мајка, чунки од многу синови Божинови само Силјан беше останал жив. (Силјан Штркот)

Анализа на синтаксата на речениците во кои се употребени анафорските субјекти во форма на лично име/ИС покажуваат дека тие почесто се појавуваат во главни реченици отколку во зависни (88 наспроти 16) со помало AР во анализираните текстови. Необично е дека само 18 примери имаат поголемо АР (над 10 реченици) во главната реченица. Ова може да се објасни со доста мала застапеност на личните заменки во сите текстови, посебно во Силјан Шйркой. 
Табела 4. Дистрибуција на лично име/ИС во анализираните текстови

\begin{tabular}{ccccc}
\hline $\begin{array}{c}\text { АР }- \text { бр. на } \\
\text { реченици }\end{array}$ & $\begin{array}{c}\text { Зависна } \\
\text { реченица }\end{array}$ & $\begin{array}{c}\text { Координативна } \\
\text { реченица }\end{array}$ & $\begin{array}{c}\text { Главна } \\
\text { реченица }\end{array}$ & Вкупно \\
\hline 1 & 5 & 2 & 31 & 39 \\
2 & 6 & 1 & 19 & 26 \\
3 & 4 & & 8 & 12 \\
$4-9$ & 1 & & 5 & 14 \\
10 & & & 3 & 5 \\
$11-19$ & & 3 & 10 & 3 \\
20 & 16 & & 88 & 109 \\
\hline Вкупно: & & & & \\
\hline
\end{tabular}

Влијанието на семантичкиот фактор се пројавува во употреба на ИС наместо очекуваната заменка/ЛГФ кога има мало АР. Тоа се случува при воведување на втор протагонист кој нема директна интеракција со првиот протагонист (Fox 1984: 170). Ако вториот протагонист е од ист број и род за да се избегне референциска двосмисленост се употребува ИС наместо заменка или ЛГФ (24). Исто така, ИС се употребува и за насочување на вниманието на читателот од еден на друг протагонист кога се работи за двајца протагонисти, означени со $\varnothing_{\text {мн }}$ во (25).

(24) Бојан и Денко веднаш стануваат другари. Иако Денко 1 е градско дете, $\varnothing_{1}$ веднаш го прифаќа Бојан 2 , а со мали потешкотии и начинот на живот во планината. Бојан 2 како домаќин го шета Денко 1 насекаде, $\varnothing_{2}$ покажувајќи му ги сите убавини на планината. (Бојан)

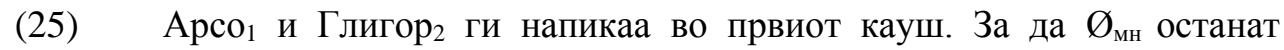
незабележани, Ø мн се измешаа со другите затвореници. Но, тука, како и насекаде каде што живеат луѓе, имаше будни очи што ги демнеа новопристигнатите. Арсо 1 најде едно незафатено местенце под прозорецот, ... (во 6 реченици референца на Арсо со Ø). Глигор 2 остана во мешаницата.(Пустина)

Дискурсниот принцип делува на границите на наративните целини. Бидејќи употребата на помаркирани форми помага да ја следиме хиерархиската структурата на наративот (Fox 1984: 166), ИС се употребува на почетокот на текстуалните целини. Другите средства се користат кога има 
отстапувања во главната раскажувачка линија. Така, за да се промени фокусот на раскажувањето, протагонистот Ѓор́́ија (26) пак се појавува по шест реченици со лично име по претходното спомнување преку ЛГФ.

(26) Поради тоа $\varnothing_{1}$ се научи да не реагира веќе толку бурно на реченицата студениот фронт ќе се придвижи кон истокот туку $\varnothing_{1}$ ги отвараше очите и $\varnothing_{1}$ мирно чекаше да заврши прогнозата. Кога $\varnothing_{1}$ ќе станеше да појадува, бабата 2 стоеше на прозорецот од кујната и $\emptyset_{2}$ ги гледаше минувачите како одат на работа или $\varnothing_{2}$ безобразно звереше во прозорецот на соседите отспротива. Кога Ѓорѓија кујната, таа 2 ќе се свртеше, не поздравувајќи се за добро утро и $\varnothing_{2}$ ќе почнеше да зборува.... (Болеро)

Слично објаснување може да се понуди и за следниот пример (27), во кој е употребено лично име по мало АР. Иако нема пауза во спомнувањето на протагонистот, што се гледа во означените анафорските субјекти со ЛГФ во серија последователни настани, употребено е лично име. Сметаме дека тоа е заради нарушување на единството на време: минатиот настан (сигнализиран co $\bar{u}$ peg $\bar{u} о a)$ ја прекинува низата на настаните и го менува концептуалниот домен.

(27) Со тие зборови и друзи Силјан 1 целата ноќ си ја поминал ... (следат 13 јадрени реченици во кои на субјектот Силјан се упатува со ЛГФ) Колку еден саат што $\emptyset_{1}$ одил, пак $\emptyset_{1}$ нашол извор со вода и чунки $\emptyset_{1}$ одел прекутрупа, на многу места $\varnothing_{1}$ наоѓал јаготки и $\varnothing_{1}$ си јадел. Тоа само му било мака, што $\emptyset_{1}$ не можел да види некаков пат и $\emptyset_{1}$ да види некоја човечка трага. Пред тоа Силјан $\varnothing_{1}$ да најде некоја трага и до кај пладне $\varnothing_{1}$ го изодил угорното, та $\varnothing_{1}$ се качил на планината... (Силјан Штркот)

ИС се употребува по дигресија поврзана со некаков опис или размислувања на протагонистот. Кога страничната линија на раскажувањето завршува, главната линија може да продолжи со употреба на анафорската ИС или заменка.

(28) Глигор 1 го завлечка Арса 2 во оддалечениот агол, до разурнатиот оџак. Во темнината, масата се разлеа и го зафати сиот простор, потече и се згусти во теснината на ходникот. Бесот премина во другите кауши. Кој, кога и зошто удираше во темнината? Глигор 1 и $\mathrm{Apco}_{2}$ тоа не можеа да го сфатат. (Пустина) 


\section{5 Заклучок}

Во ова истражување ги испитувавме формите на субјектните ИС во наративните текстови на македонски јазик. За таа цел ги користевме современите теории за дистрибуција на референциски изрази во дискурсот. Со помош на квантификативна метода ги утврдивме законитостите што ги определуваат реализациите на субјектната анафора. Резултатите ја потврдија појдовната хипотеза дека изборот на субјектните анафорски форми примарно ce определува од когнитивниот принцип на ментална достапност. Но принципот на немаркирано бележење на анафори чии референти имаат висока ментална достапност може да се наруши заради неколку универзални принципи чие делување предизвикува отстапување од очекуваните реализации на субјектните ИС.

Со оглед на фактот дека за македонскиот јазик не постојат слични истражувања од областа на дискурсната анализа сметаме дека презентираните резултати ќе придонесат за подлабоко разбирање на организацијата на наративните текстови.

\section{Библиографија}

Ariel, M. (1988). Referring and Accessibility. Journal of Linguistics, 24 (1): 65-87.

Brown, G. and Yule, G. (1983). Discourse analysis. Cambridge: Cambridge University Press.

Chafe, W. L. (1987). Cognitive constraints on information flow. In R. S. Tomlin (ed.). Coherence and grounding in discourse, 21-52. Amsterdam: John Benjamins.

Clerk, S. A. (2000). Participant Reference in Narrative Discourse: a comparison of three methodologies. MA thesis. North Dakota: University of North Dakota.

Comrie, B. (1989). Language Universals and Language Typology. Oxford: Blackwell.

Downing, A. and Locke, P. (2006). English Grammar: A University Course. New York: Routledge.

Fox, B. (1987). Anaphora in popular written English narratives. In R. S. Tomlin (ed.). Coherence and grounding in discourse, 156-172. Amsterdam: John Benjamins.

Fauconnier, G. (1994). Mental Spaces: Aspects of Meaning Construction in Natural Language. Cambridge: Cambridge University Press.

Givón, T. (1983). Topic continuity and word-order pragmatics in Ute. In T. Givón (ed.). Topic continuity in discourse, 145-195. Amsterdam: John Benjamins.

Givón, T. (2001). Syntax: An introduction-a functional-typological approach. Vol. 2. Rev. ed. Amsterdam: John Benjamins.

Gundel, J. K., Hedberg, N. and Zacharski, R. (1993). Cognitive Status and the Form of Referring Expressions in Discourse. Language, 2: 274-307.

Langacker, R. W. (2001). Discourse in Cognitive Grammar. Cognitive Linguistics, 12 (2): $143-188$. 
Lambrecht, K. (1994). Information structure and sentence form: topic, focus, and the mental representation of discourse referents. Cambridge: Cambridge University Press.

Levinsohn, S. H. (2000). Discourse features of New Testament Greek. 2nd ed. Dallas, Texas: SIL International.

Nichols, J. (1985). The Grammatical Marking of Theme in Literary Russian. In M. Flier and R. Brecht (eds). Issues in Russian Morphosyntax, 170-186. Columbus, Ohio: Slavica

Runge, S. E. (2006). A Discourse-Functional Description of Participant Reference in Biblical Hebrew Narrative. Doctoral dissertation. Stellenbosch: University of Stellenbosch.

Travis, E. and Calcoullos R. T. (2012). What do subjects do in discourse? Cognitive, mechanical and constructional factors in variation. Cognitive Linguistics, 23 (4): 711748.

van Hoek, K. (1997). Anaphora and Conceptual Structure. Chicago: University of Chicago Press.

van Vliet, S. (2009). Reference points and dominions in narratives. In V. Evans and S. Pourcel (eds). New Directions in Cognitive Linguistics, 441-464. Amsterdam: John Benjamins. 